\title{
Prinsip Utilitarisme sebagai Dasar Hidup Bermasyarakat
}

\author{
Yogie Pranowo \\ Litbang Sekolah Santo Yakobus \\ yogie.pranowo@yakobus.sch.id
}

\begin{abstract}
This research starts from cases of ethical violations that occur in the society. The purpose of this study is to see whether the principle of utilitarism is the most appropriate ethical principle applied in social life. The method used in this study includes descriptive qualitative methods and uses a critical paradigm. The results show that the principle of utilitarism is the most appropriate principle used in a particular leadership context, which emphasizes the benefits for the majority.
\end{abstract}

Keywords: Utilitarism, Society, Ethical Violations, Freedom

\section{PENDAHULUAN}

Atmosfer Covid-19 ini menyebabkan manusia mengalami keterasingan atas hidupnya. Hampir semua aspek kehidupan manusia berubah dan dalam keterbatasan itulah, manusia diuji, sebab dalam kondisi tertekan secara psikologis, manusia akan menjadi dirinya sendiri. Siapa sangka di zaman yang serba mewah dan canggih ini, ternyata terjadi serangan dari virus mematikan yang juga mematikan beberapa sendi kehidupan manusia yang katanya makluk ciptaan Tuhan.

Ironisnya, ketika banyak orang yang hidup diambang batas kehidupan yang layak, ada sekumpulan orang yang tega melakukan penipuan, mulai dari penipuan pembelian online, hingga penipuan harga diri dalam bentuk prank dari Youtuber yang akhirnya dipenjara. Padahal, mengenai hal ini, Driyarkara, seorang filsuf dari Indonesia pernah mengatakan bahwa eksistensi manusia dalam hubungannya dengan sesama adalah sebagai homo homini socius: manusia adalah kawan bagi sesamanya, kawan yang membantu menjadi semakin manusiawi dan kawan yang ikut mengantarnya menuju ke pusat hidup manusia yakni, Tuhan. Singkatnya, ia mengkritik hubungan antar manusia yang semakin memakan dan sering membenci, sebagaimana homo homini lupus: manusia adalah serigala bagi sesamanya (Driyarkara, 2016). Adanya perbedaan ini tentunya menjadi masalah. Driyarkara menawarkan sebuah konsep yang ideal bagi manusia, yakni homo homini socius, sedangkan realita yang terjadi di masyarakat malah sebaliknya, manusia menjadi makluk yang saling memakan satu sama lain, mereka saling mengobjekkan diri sendiri. Berdasarkan pengobjekkan diri itulah yang menyebabkan manusia menemui banyak persoalan dalam hal kemanusiaan. Persoalan kemanusiaan tersebut sebenarnya dapat diatasi jika manusia mau merefleksikan hidupnya dengan lebih serius lagi. Artinya, manusia harus mampu memberikan makna kepada dirinya. Hal itu dapat ditempuh melalui etika.

Pada sejarah perkembangan pemikiran dan teori etika, utilitarisme dapat dikategorikan ke dalam teori etika 
normatif yang mempunyai peranan yang sama dengan teori etika normatif lainnya yakni untuk mencari jawaban atas problem pokoknya, yaitu bagaimana mempertanggungjawabkan secara rasional penilaian dan putusan moral. Penilaian dan putusan moral yang dapat dipertanggungjawabkan secara rasional adalah penilaian dan putusan yang didasarkan pada prinsip dan norma moral yang sehat. Lantas pertanyaan selanjutnya adalah, manakah prinsip dan norma moral yang sehat yang dapat dijadikan acuan dan dasar pertanggungjawaban rasional bagi penilaian dan putusan moral? mengenai pertanyaan itu rupanya tidak ada kesepahaman, sehingga kesimpulannya, dalam sejarah filsafat ada beberapa teori etika normatif.

Secara garis besar, dalam teori etika normatif dapat dikategorikan menjadi dua kelompok kategori. Kelompok pertama adalah kelompok teori konsekuensialis, dan kelompok kedua adalah teori non-konsekuensialis. Kelompok teori yang konsekuensialis ini menilai baik buruknya perilaku manusia berdasarkan konsekuensi atau akibatnya, dengan kata lain, akibat perbuatan atau tindakan seseorang harus dilihat apakah membawa akibat baik lebih banyak daripada akibat buruknya atau sebaliknya, sedangkan yang nonkonsekuensialis menilai baik buruknya perilaku manusia tanpa memperhitungkan konsekuensi atau akibatnya, melainkan berdasarkan kesesuaian tindakan dengan hukum atau standar moral. Salah satu teori yang termasuk dalam kelompok konsekuensialis ini adalah teori etika utilitarisme, sedangkan salah satu teori yang termasuk dalam nonkonsekuensialis adalah teori etika deontologist Kant (Sudarminta, 2013).

\section{METODE}

Penelitian ini menggunakan metode deskriptif analitis dengan paradigma kritis. Pada penelitian ini, penulis akan menelusuri apa sesungguhnya yang melatarbelakangi kasus-kasus pelanggaran etika di masyarakat berdasarkan anasir-anasir yang ada. Tahap selanjutnya penulis akan menguraikan pokok-pokok pemikiran etika terkait kehidupan bermasyarakat, sehingga dapat ditemukan kesimpulan yang tepat atas penelitian ini.

\section{HASIL DAN PEMBAHASAN}

\section{Utilitarisme}

Utilitarianisme berasal dari kata Latin utilis, yang berarti manfaat atau guna. Ulilitarisme adalah paham atau aliran dalam filsafat moral yang menekankan prinsip manfaat atau kegunaan sebagai prinsip moral yang paling dasar. Tindakan yang secara moral benar adalah tindakan yang berguna. Suatu tindakan dinilai berguna kalau akibat tindakan tersebut secara keseluruhan, dengan memperhitungkan semua pihak yang terlibat dan tanpa membeda-bedakan orang, membawa akibat baik berupa keuntungan atau kebahagianan yang semakin besar bagi semakin banyak orang. The greatest good to the greatest number merupakan diktum yang selalu didengungkan oleh utilitarisme. Paham ini menyatakan bahwa diantara semua tindakan yang di ambil atau diantara semua peraturan yang sejauh dapat diperhitungkan akan paling memajukan kepentingan banyak orang atau paling membawa kebahagiaan mereka. Utilitarianisme sebagai teori sistematis pertama kali dipaparkan oleh Jeremy Bentham dan muridnya, John Stuart Mill.

Ciri umum Utilitarisme adalah bersifat kritis, rasional, teleologis dan 
universal. Utilitarisme sebagai teori etika normatif merupakan suatu teori yang kritis karena menolak untuk taat terhadap norma-norma yang berlaku begitu saja. Utilitarisme menuntut agar diperlihatkan mengapa sesuatu dilarang atau sebaliknya diwajibkan yang memberi nilai moral terhadap tindakantindakan atau peraturan tersebut adalah akibat-akibatnya. Contohnya, para penganut aliran Ulilitarisme tidak dapat menerima begitu saja bahwa hubungan seks diluar perkawinan, sebagaimanapun juga pada dirinya sendiri tidak pernah dapat dibenarkan secara moral. Mereka akan bertanya mengapa tidak boleh melakukan hubungan seks diluar perkawinan, mereka akan menuntut agar dapat diberikan alasan-alasan yang masuk akal. Dengan demikian, rasionalitas penilaian moral atas tindakan ataupun pemberlakuan suatu peraturan moral ditentukan oleh lebih banyaknya akibat baik yang ditimbulkan dibandingkan dengan akibat buruknya.

Sifat kritis dan rasional Ulilitarisme dalam kalangan etika tradisional dialami sebagai kritik yang membahayakan bagi kepatuhan terhadap norma-norma moral yang secara tradisional berlaku, daripada menerima aturan-aturan tradisional begitu saja, Ulilitarisme menuntut agar peraturan-peraturan yang ada dipertanggungjawabkan berdasarkan manfaat bagi banyak orang dan apabila pertanggungjawaban itu tidak dapat dilakukan, peraturan tersebut supaya dilepaskan.

Ulilitarisme juga bersifat teleologis, karena benar-salahnya suatu tindakan secara moral dikaitkan dengan tujuan (telos) yang mau dicapai atau dengan memperhitungkan apakah akibat baik tindakan tersebut lebih banyak daripada akibat buruknya. Hal ini berbeda dengan para penganut etika deontologis. Bagi para penganut Deontologis, ada tindakan-tindakan tertentu yang pada dirinya sendiri tidak pernah dapat dibenarkan secara moral, entah apa pun akibat tindakan tersebut. Bagi Deontologis norma-norma moral selalu wajib diatasi begitu saja tanpa mempertimbangkan apakah akibatnya menguntungkan atau merugikan. Utilitarisme juga bersifat universal dalam arti teori etika ini memperhatikan kepentingan umum dan bukan hanya kepentingan pribadi pelaku moral.

Ada dua macam teori etika utilitarisme, yakni utilitarisme tindakan dan utilitarisme peraturan. Utilitarisme tindakan dirumuskan sebagai berikut "Bertindaklah sedemikian rupa sehinga setiap tindakan mu itu menghasilkan akiba-akibat baik yang lebih besar didunia dari pada akibat buruknya." Pernyataan pokok yang perlu diajukan dalam mempertimbangkan suatu tindakan tertentu adalah "Apakah tindakanku yang tertentu ini, pada situasi seperti ini, kalau memperhatikan semua pihak yang tersangkut, akan membawa akibat baik yang lebih besar dari pada akibat buruknya?" Utilitarisme tindakan sudah banyak dikritik dan hampir tidak ada yang membelanya lagi dengan alasan: dalam praktiknya orang tidak setiap kali membuat pertimbangan baru untuk melihat akibat-akibat dari setiap tindakan.

Utilitarisme tindakan dengan
mudah dapat dipakai untuk
membenarkan tindakan yang melanggar hukum dengan alasan akibatnya membawa keuntungan yang melanggar hukum dengan alasan bahwa akibat buruknya. Misalnya, berdasarkan prinsip itu seseorang dapat dibenarkan untuk mencuri makanan dari supermaket untuk diberikan kepada orang gelandangan yang kelaparan, jika hanya memperhitungkan akibat 
kerugian yang diderita oleh supermaket karena dicuri makanannya akan tidak seberapa dibandingkan dengan keuntungan memberi makan pada beberapa orang gelandangan yang kelaparan.

Cara mengatasi kelemahan tersebut dengan dikembangkan utilitarisme peraturan. Teori ini yang diperhitungkan bukan lagi akibat baik dan buruknya dari masing-masing tindakan sendiri, melainkan peraturan umum yang mendasari tindakan itu. Kaidah dasarnya berbunyi "Bertindaklah selalu sesuai dengan kaidah-kaidah yang penerapanya menghasilkan akibat baik yang lebih besar di dunia ini daripada akibat buruknya." Jika kaidah ini diterapkan pada kasus pencurian makanan di supermarket, menjadi nyata bahwa tindakan itu tidak dapat dibenarkan karena "mengambil barang di toko tanpa bayar boleh dilakukan asal untuk orang miskin" tidak dapat dijadikan sebagai kaidah yang berlaku umum, sebab dapat dipastikan bahwa akibat buruknya akan jauh lebih besar daripada akibat baiknya. Hal ini berlawanan dengan prinsip utulitarisme.

\section{Utilitarisme Bentham}

Jeremy Bentham (1748-1832), seorang ahli filsafat moral dari Inggris mengemukakan doktrin utilitarisme. Ide pokok dari doktrin ini adalah bahwasanya prinsip tertinggi moralitas adalah memaksimalkan kebahagiaan melampaui kesakitan. Bagi Bentham, hal tepat yang dilakukan terhadap segala sesuatu adalah memaksimalkan utilitas (Sandel, 2009). "Dengan utilitas dimaksudkan sifat dalam setiap objek yang cenderung menghasilkan manfaat, keuntungan, kesenangan, kebaikan atau kebahagiaan, atau untuk mencegah terjadinya kerugian, kesakitan, kejahatan, atau ketidakbahagiaan kepada pihak yang kepentingannya dipertimbangkan: jika pihak yang dipertimbangkan itu menjadi komunitas secara umum, maka kebahagiaan itu adalah individu" (Bentham, 2005).

Maksud dari utilitas ini adalah pengusahaan segala sesuatu untuk menghasilkan rasa senang atau pengusahaan segala sesuatu untuk mencegah rasa sakit ataupun penderitaan. Adapun pandangan anthropologis Bentham adalah manusia seluruhnya dipengaruhi oleh rasa sakit dan senang. Rasa itulah yang menjadi penguasa atas diri manusia. Semua manusia menyukai rasa senang dan tidak menyukai rasa sakit (Sandel, 2009). Pandangan utilitarian mengakui fakta ini dan membuatnya menjadi hidup moral dan politik termasuk dalam pemerintahan. Hukum dan kebijakan yang berlaku diputuskan dalam sebuah pemerintahan, harus berbuat segala sesuatu yang akan memaksimalkan kebahagiaan komunitas secara keseluruhan. Apa itu komunitas? menurut Bentham, komunitas adalah kesatuan tubuh khayalan, yang terdiri atas jumlah individu-individu yang menyetujuinya. (Sandel, 2009).

Jika prinsip utilitas ini diterapkan dalam pemerintahan, baik pelaksanaan kebijakan Negara maupun masyarakat yang menerima kebijakan Negara itu harus bertanya pada dirinya sendiri bahwa jika sebuah kebijakan mendatangkan keuntungan, apakah kebijakan itu akan mendatangkan lebih banyak rasa senang dari pilihan yang lain. Bagi Bentham, seluruh perdebatan moral yang terjadi berkaitan dengan ketidaksetujuan pada penerapan utilitarian dan bukan pada prinsip itu sendiri. (Sandel, 2009)

Utilitarisme mengaitkan moralitas suatu tindakan dengan jumlah akibat baik yang melebihi akibat 
buruknya, maka pertanyaan selanjutnya adalah bagaimana nilai suatu akibat itu dapat ditentukan. Maksud dari utilitas ini adalah pengusahaan segala sesuatu untuk menghasilkan rasa senang atau pengusahaan segala sesuatu untuk mencegah rasa sakit ataupun penderitaan. Pandangan tentang anthropologis Bentham adalah manusia seluruhnya dipengaruhi oleh rasa sakit dan senang. Rasa itulah yang menjadi penguasa atas diri manusia (Bentham, 2005). Utilitarianisme merupakan suatu paham etis yang berpendapat bahwa yang baik adalah yang berguna, berfaedah, dan menguntungkan. Sebaliknya, yang jahat atau buruk adalah yang tak bermanfaat, tak berfaedah, dan merugikan. Karena itu, baik buruknya perilaku dan perbuatan ditetapkan dari segi berguna, berfaedah, dan menguntungkan atau tidak.

Menurut pandangan kaum utilitarianisme, tujuan perbuatan yang menghindari atau mengurangi kerugian yang diakibatkan oleh perbuatan yang dilakukan, baik bagi diri sendiri ataupun orang lain. Adapun maksimalnya adalah dengan memperbesar kegunaan, dan keuntungan yang dihasilkan oleh perbuatan yang akan dilakukan. Perbuatan harus diusahakan agar mendatangkan kebahagiaan daripada penderitaan, manfaat daripada kesiasiaan, keuntungan daripada kerugian, bagi sebagian besar orang. Dengan demikian, perbuatan manusia baik secara etis dan membawa dampak sebaik-baiknya bagi diri sendiri dan orang lain.

jika kita mau memakai kelebihan akibat baik terhadap akibat buruk sebagai tolok ukur moral, maka kita harus tau apa arti "Lebih Besar" dalam hubungan nilai. Cara menghitung lebih besarnya akibat- akibat baik atau buruk adalah dengan cara membatasi diri pada pembandingan akibat tindakan dari segi nilai kenikmatan saja. Namun rupanya cara seperti ini menemui kesulitannya sendiri. Rasa nikmat ada bermacam-macam dan sulit dibandingkan, kenikmatan karena memuaskan nafsu makan, nafsu seks, nafsu marah, nafsu balas dendam, kenikmatan tidur, kenikmatan merokok, naik gunung, berenang, dan sebagainya. Kesulitan menjadi lebih besar jikalau masih harus membandingkan besar kecilnya akibat baik dan buruk yang di timbulkannya. Contohnya adalah sulit sekali untuk menentukan mana dari kemungkinan tindakan berikut yang paling besar membawa kenikmatan sebagai akibatnya misalnya pergi menonton film, makan sate ayam bersama teman, atau membaca buku filsafat sambil mendengarkan musik yang kita senangi? untuk menjawab pertanyaan itu Jeremy Bentham mencoba untuk memperhitungkan nilai senang dari berbagai kegiatan manusia guna dapat diperbandingkan jumlahnya satu sama lain.

Ia mengemukakan ada tujuh dimensi yang perlu diperhatikan dalam perhitungan, yakni intensitasnya, lamanya berlangsung, kepastiannya, kedekatannya dengan kecondongan pribadi, kesuburannya, kemurniannya, dan keluasannya.

Utilitarisme Bentham memiliki ciri:

(1) Orang menjadi bahagia sejauh mereka merasa senang, sebaliknya, orang tidak merasa bahagia sepanjang mereka merasa sakit. Oleh karena itu orang akan berusaha mencari rasa senang dan segala sesuatu apapun bentuknya, hanya sarana untuk menjadi bahagia, dan segala sesuatu itu dipandang hanya sejauh mereka menimbulkan rasa senang.

(2) Utilitarisme menghitung semua rasa senang dan rasa sakit, dan memperlakukan setiap jenis rasa 
senang dan rasa sakit sebagai setara. Jika kuantitas dihitung sama, maka sebagai contoh kenikmatan mengejek seseorang sama halnya rasa senang membantu seseorang. Kenikmatan memiliki pekerjaan yang sukses, sama dengan kenikmatan makan es krim sangat banyak. Hal yang sama berlaku untuk rasa sakit. Rasa sakit bahwa seseorang merasa dihina, sama dengan kenikmatan yang dirasakan dari orang yang menghina.

(3) Pembenaran mengorbankan seseorang demi kebahagiaan mayoritas, jika kebahagiaan masyarakat lebih besar tampak pada pengucuran dana untuk membiayai klub Persija daripada untuk bantuan dana kesehatan orang miskin, maka prinsip utilitas memberitahu kita untuk mengucurkan dana kepada Persija saja karena menimbulkan kebahagiaan bagi banyak orang sekalipun mengorbankan penderitaan sejumlah kecil orang sakit yang membutuhkan bantuan dana kesehatan.

Dari uraian tersebut, setidaknya kita dapat menemukan dua kelemahan dalam teori utilitarisme Bentham. Pertama, ia kesulitan untuk menentukan nilai suatu akibat. Ia tidak dapat memberikan penialaian yang "adil" terhadap rasa nikmat, rasa sedih, rasa senang, dan sebagainya. Kedua, prinsip utilitarisme Bentham bertentangan dengan keadilan. Contohnya adalah mengenai kebijakan yang diambil oleh Pemerintah berkenaan dengan pembangunan jalan layang. Proses pembuatan jalan layang tersebut, pemerintah melakukan penggusuran (paksa) terhadap orang yang tinggal di jalur perencanaan jalan layang tersebut walaupun pemerintah juga memberikan uang ganti rugi terhadap pihak yang digusur. Menurut kacamata utilitarisme, pemerintah logis dan benar, namun itu berarti, pemerintah mengorbankan manusia demi manusia lain. Padahal menjadikan manusia yang minoritas sebagai tumbal yang harus dikorbankan demi kesejahteraan banyak orang secara moral tak dapat dibenarkan.

kasus etika yang pernah menggegerkan dunia intelektual dan para etikawan terjadi pada awal tahun 2000-an. Kasus ini adalah kasus perdebatan antara Pemerintah Rep Ceko dengan perusahaan rokok Philip Morris. Pemerintah Ceko merasa cemas akan meningkatnya pembiayaan kesehatan yang bersumber dari pajak karena efek dari merokok. Sebagai tanggapan atas situasi tersebut, Phillip Morris membuat analisis untung rugi dampak dari merokok bagi keuangan Negara.

Hasil analisa Phillip Morris adalah pemerintah Ceko sebenarnya memperoleh pendapatan yang besar dari pada biaya yang dikeluarkan karena penduduknya merokok. Pandangan yang dikemukakan perusahaan adalah walaupun para perokok memicu pengeluaran anggaran kesehatan yang lebih besar, karena mereka lekas meninggal, maka ada penghematan pemerintah dari total pengeluaran untuk perawatan kesehatan, uang pensiun, dan rumah jompo. Jumlah penghematan itu ternyata lebih besar dari pengeluaran untuk perawatan kesehatan akibat rokok. Kesimpulan dari Phillip Morris adalah Negara justru diuntungkan dengan kehadiran perusahaan rokok tersebut. (Fairclough, 2001). Akan tetapi setelah mendapat tekanan dari publik terutama dari para aktivis antirokok, pimpinan perusahaan rokok tersebut minta maaf karena penelitian yang dilakukan telah tidak menghiraukan nilai dasar manusia. 
Studi kasus tersebut menunjukkan analisa untung rugi menggantikan nilai manusia, sehingga tampak kelemahan dari ide utilitarisme yang kerap terlupakan oleh banyak orang. Utilitarisme kerapkali menjadikan manusia sebagai dimensi statis yang boleh dieksploitasi sedemikian rupa sehingga dapat menguntungkan pihak-pihak tertentu. Berkenaan dengan hal ini, Aristoteles dan Kant, sebagai penjaga pintu moral di titik ekstremnya masing-masing memberikan penilaian berbeda mengenai utilitarisme ini.

Aristoteles dalam Nichomacean Ethics mengatakan "Setiap seni dan penelitian dan dengan demikian pula setiap tindakan dan pengejaran, dianggap bertujuan pada kebaikan, dan untuk itulah kebaikan dengan tepat dinyatakan sebagai tujuan". (Aristoteles, 2009).

Dari pernyataan di atas, kita dapat melihat bahwa aristoteles sebenarnya membicarakan tentang tujuan sebuah tindakan moral. Hal tersebut juga menjadi salah satu ciri dari utilitarisme, yakni memiliki telos. Bagi aristoteles, salah satu unsur dalam kebahagiaan adalah kenikmatan atau rasa senang. Baginya, kenikmatan atau rasa senang merupakan hasil hidup berkeutamaan. Hal ini juga kental dalam ide utilitarisme yang menekankan kesenangan dan kenikmatan (Sudarminta, 2013). Perbedaan antara etika aristoteles (eudaimonisme) dengan utilitarisme terletak pada subjeknya. Jika pada utilitarisme lebih menekankan kebahagiaan bagi sebanyak mungkin orang, bagi eudaimonisme, lebih menekankan kebahagiaan yang egosentris.

Posisi yang berlainan dengan Aristoteles, ada kaum deontologist Kant, yang jelas berlawanan dan terus saja mempertanyakan ide utilitarisme, yang (katanya) cenderung bersifat kekanak-kanakan. Sebab bagi kaum deontologist, yang penting dari sebuah tindakan moral adalah kewajiban, tak peduli dengan tujuannya apa. Hal inilah yang terus menerus didengungkan oleh kaum deontologist. Sebab, deontologist Kant sebenarnya berpretensi menjamin otonomi dan keluhuran martabat manusia dan menjamin keadilan, tidak seperti utilitarisme yang tak memperhatikan itu.

Dengan demikian kita dapat melihat bahwa, Aristoteles ada di belakang ide utilitarisme karena samasama mengusung tujuan sebuah tindakan, sedangkan deontologis Kant bertentangan dengan Aristoteles dan utilitarisme, sebab lebih menekankan keuniversalan dan "hal luhur" dari sebuah kewajiban sebagai dasar tindakan moral.

\section{PENUTUP}

Penerapan utilitarisme di tengah masyarakat adalah tepat jika diterapkan dalam konteks mementingkan mayoritas atau suara terbanyak dan demi keuntungan sebanyak mungkin orang.

\section{DAFTAR PUSTAKA}

Aristoteles. (2009). The Nicomachean Ethics. Translated by David Ross. Oxford: Oxford University Press.

Bentham, J. (2005). An Introduction to The Principle of Morals and Legislation. Oxford: Clarendon Press.

Bertens, K. (1993). Etika, Jakarta: Gramedia Pustaka Utama.

Driyarkara, N (Ed.). (2006). Karya Lengkap Driyarkara. Esai-Esai Filsafat Pemikir yang Terlibat Penuh dalam Perjuangan Bangsanya. Jakarta: Gramedia. 
Jurnal Filsafat, Sains, Teknologi, dan Sosial Budaya

Volume 26, Nomor 2, Oktober 2020

Fairclough, G. (2001). Philip Morris Notes Cigarettes Benefit for Nation Finances. Wallstreet Journal, 2(1) 12-24.

Sandel, M. (2009). Justice: What the Right Thing To Do?, New York: Farrar, Straus and Giroux.

Sudarminta, J. (2013). Etika Umum. Kajian tentang Beberapa Masalah Pokok dan Teori Etika Normatif, Yogyakarta: Kanisius. 